\title{
Scientific researches on the journalism esp in foreign universities and in Uzbekistan journalism and mass communication university
}

\author{
Mukarram Otamurodova \\ Master student of Uzbekistan journalism \\ and mass communications university \\ E-mail: $\underline{\text { mukarram@gmail.com }}$
}

\begin{abstract}
This article learns the experiences of several foreign universities professionally oriented English teaching in the field of journalism. It also discusses journalism education, the specifics of language teaching, and ongoing research in countries where English is taught as a second or foreign language. The achievements and practical results of teaching English in the journalism faculties of prestigious universities are discussed. The studying of Uzbek researchers on journalism ESP is analyzed and some lacks of the work investigated in the article.
\end{abstract}

Keywords: English, journalism education, ESP, module, teaching materials

\section{Introduction}

The issue of knowing and teaching English, which is becoming the language of modern science and education, has been identified as one of the top priorities of the education system in most countries of the world. The education system of countries where this language is not the main language has developed different stages, methods and approaches to teaching it, and even several targets. One of the researches in this field is English for Specific Purposes (ESP for short), which is the teaching of a foreign language in a certain activity and profession. This language teaching field, which is used as ESP in all languages, has a short history.

The emergence of ESP is directly related to the end of World War II and its aftermath. This trend has emerged due to the development of the world economy, the development of technology, the economic power of oil-rich countries and the increase in the number of foreign students in English-speaking countries are also key factors.

As all fields, journalism is not left out of mastering the beneficial effects of English language development. It is difficult to imagine media activities in the field of language and communication without a foreign language. That's why great emphasis is also placed on teaching English at leading universities in the field of media education. The intensity of the globalization process has led to an increase in the flow of English-language information in the media space. Many universities teach ESP as an assistant subject in mastering professional majors. It means, English is considered not only for general communication, but also as a tool in mastering the theory of the specialty being studied.

According to a group of researchers at the University of Dubrovnik: "The global role of today's media and the need to be competitive in professional activities require the active use of English" The need for English and knowledge of lingua franca within the field is just as important for journalists as knowing their own language.

A lingua franca is a neutral language that does not claim ownership of a mother language among people whose native languages are different. The term was firstly used by crusaders and merchants in the eastern Mediterranean.

\section{Main part}

The history of world shows that each long periods had its own lingua franca. Greek and Latin gave this status to French in the 18th century. After World War II, English began to take its place. Like all other fields, journalism is being enriched with English words which are internationally understandable. As an example "communication", "news", "information", "fact-checking", "media" etc. However, every journalist who aspires to be a leader in his or her career is not limited to lingua franca of the branch. Anna Zelenovskaya suggests: "journalists need to possess intercultural professional communication skills to study foreign experience in their field and communicate with their foreign counterparts.

"Professional communication is a key term for professional activities and comes in many forms, including verbal, nonverbal, and distant" -says American researcher Karen Schriver. Unlimited possibilities of the World Wide Web and digital technologies are creating chances for interaction with colleagues all over the world. Journalists from 
various strategic locations on the Earth can also exchange ideas and discuss news in the sphere with the help of an intermediary language. In addition, working with foreign sources, analyzing them and evaluating reliability of original sources can be achieved through mastering a foreign language.

For this reason, currently, there is ongoing research on the training of qualified journalists for teaching foreign languages in conjunction with new media trends. In addition to general communication, it is necessary to balance foreign languages with the terminology and professional peculiarities if the field in order to build communication skills within professional activities. In this process "the foreign language is integrated with the core disciplines and begins to function as a means of complementing professional knowledge."

\section{Analyses}

To guide future journalists to transfer media knowledge and world experience to independent learning through the development of perceptive and receptive skills is one of the objectives of the modeling lesson. The content and potential of educational literature should be taken into account in achieving these objectives. In international practice, each institution of higher education has different approaches in this regard. "Croatian universities will be included in the syllabus from the second semester of English studies in journalism courses. After the course "English basis for Journalist" is taught for one semester, the following steps will be continued with "English as a media language". As the titles of the subjects suggest, the English language used by future journalists should be different from in other areas of activity. "In the department of Mass Communication at the university of Dubrovnik, French, German, Italian, Spanish are designated as optional subjects, while English is included in the syllabus as a mandatory subject."

According to the official website of the Moscow State University named after M. Lomonosov, the undergraduate students of the journalism faculty of the university study Spanish in 3-4 semesters and English in 5-8 semesters. However the manual "Frost an Nixon Learn English Watching Films" by E. G. Gimatdinova is chosen as a textbook and this is not a perfect guidebook for developing professional language skills as a practical manual. The content of the textbook lacks the simultaneous and interrelated development of four language skills. It would be useful to revise the textbook on media terminology.

"The ESP courses offered by Greek institutions typically run for a semester and are usually included in the core subjects of the Universities' programmes, thereby ensuring that each student will have some kind of exposure to the specific type of language used in his/her field of study together with general academic/study skills. The ESP program at the School of Journalism and Mass Communications has been well established since 1993 and its basic aim is to prepare future journalists for an international/multilingual environment. English for Journalists is a core course taught during the second semester and it presupposes a good knowledge of general English. Thus, the course caters for a B1B2 level of English for a duration of 39 hours. The number of students who are enrolled in the class is 140 per semester but only 50 regularly attend the classes on a weekly basis. It is worth mentioning here that the course also caters for the needs of exchange students who visit the School through various international agreements; every year at least 10-15 Erasmus students from different countries also attend this course.

The ESP system, launched at Aristotle University in Greece has a number of achievements that should be introduced in the journalism faculties of our universities. The division of the course into modules allows for a more indepth study of areas of the media industry, such as print media, television and radio, the Internet and international journalism, in English. Teaching similarities and differences of directions and specific terminology in such ESP lessons creates convenience for both the teacher and the student, increases the quality and effectiveness of the lesson.

There are three universities in Uzbekistan that train media cadres. As an example of the Uzbekistan Journalism and Mass Communications University where the Russian and English classes are taught compulsory. In undergraduate course, the English language classes are 4 hours per week. "face2face"( Nicholas Tims with Chris Redston \&Gillie Cunnigham) is chosen as a textbook and intended for general English learning, but it does not reflect the specifics of journalistic activity. As a complimentary literature, the monograph "Check Your Media English" by G. Khan is used, but the handbook is narrow in content and does not contribute to the development of all language skills. The manual is implied for teaching vocabulary words, and its overall content consists of texts and new words. In the annotation of the book, the author noted that it is for users with beginner and intermediate language levels. However, the fact that, one guidebook is designed for students with two different levels of language at the same time means that they do not fully understand the capabilities of the users. 


\section{Conclusions}

It is evident that, teaching English language, which is an integral part of modern journalism education, researching on the teaching materials and literature, achieving their contextual excellence are becoming a new and actual issue in the field of English for specific purposes.

Rapid developments in the field of mass media have increased the demand for journalists who can translate texts in foreign languages and prepare information in foreign languages as well. It is the responsibility of universities to meet this issue. Any university that wants to provide its cadres with modern journalistic knowledge should be well aware of the need to pay great attention to teaching English. Indeed, the world experience also shows the demand for multilingual journalists in the above examples.

\section{References}

1. Carolina Gozalez Ramirez. English for specific purposes: brief history and definition. Revista de Lenguas ModeRnas, $\mathrm{N}^{\circ}$ 23, 2015 p. 379-386.

2. David Pendery. Course and Material Design for Active ESP Journalism English Teaching.

3. Erlin Estiana Yuanti, Designing an ESP speaking for journalism class - A case study. The 61 TEFLIN International Conference.

4. Marina Tzoannopoulou, Rethinking ESP: Integrating content and language in the University classroom. Procedia - Social and Behavioral Sciences 173 (2015) p.149 - 153

5. Mukhtarov Sardorbek Saydullo ogli, Gayratova Gulzoda San'atbek qizi, \& Mamajonova Gulmira Dilbek qizi. (2020). Mahmudkhoja Behbudiy's Approach to Bekhbudiyi's Cultural Autonomy Project of Turkey and the Political Governance Policy. International Journal on Orange Technologies, 2(1), 35-39. Retrieved from http://journals.researchparks.org/index.php/IJOT/article/view/493

6. Fayzullayeva Shahzoda Akmalovna. (2020). Specific Sciences are More Important than the Humanities in the Education System. International Journal on Orange Technologies, 2(1), 29-34. Retrieved from http://journals.researchparks.org/index.php/IJOT/article/view/492

7. Rakhmonova Feruza Sherbek qizi. (2020). What disease is a coronavirus infection?. International Journal on Orange Technologies, 2(1), 25-28. Retrieved from http://journals.researchparks.org/index.php/IJOT/article/view/479

8. Farmonova M. O., \& Sultanov J. S. (2020). Some Historical Information about the Life and Mathematical Heritage of Beruni. International Journal on Orange Technologies, 2(1), 43-45. Retrieved from http://journals.researchparks.org/index.php/IJOT/article/view/495

9. Kunitsky Konstantin. (2020). Substantiation of investment component of development of property potential of economic systems in agricultural sector of economy. Middle European Scientific Bulletin, 2, 1-3. Retrieved from http://cejsr.academicjournal.io/index.php/journal/article/view/10

10. Bogdan Dergaliuk. (2020). Challenges of structural shifts in regional economic systems. Middle European Scientific Bulletin, 2, 16-18. Retrieved from http://cejsr.academicjournal.io/index.php/journal/article/view/14 